\author{
ارزيابى تنوع گونهاى گياهى زيراشكوب بين گروههاى اكولوزيك در ارتباط \\ با برخى از عوامل محيطى در جنگل هاى شهرستان باغملك \\ سينا عطار روشن "* مهلدى حيدرى

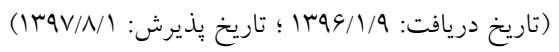

جكيده

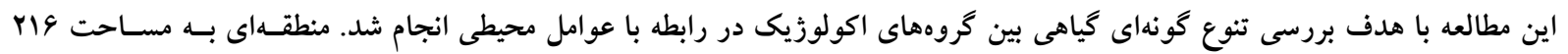

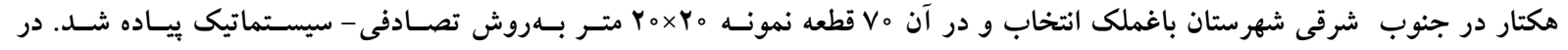

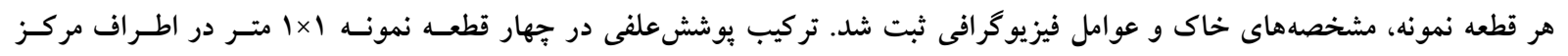

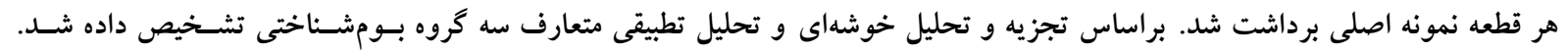

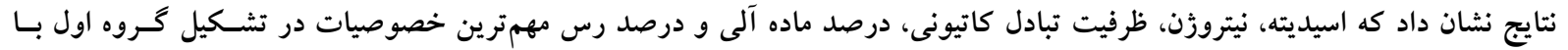

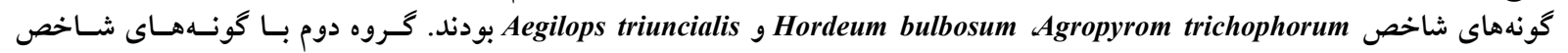
Salvia macrosiphon Bromus tectorum

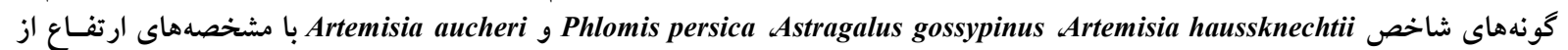

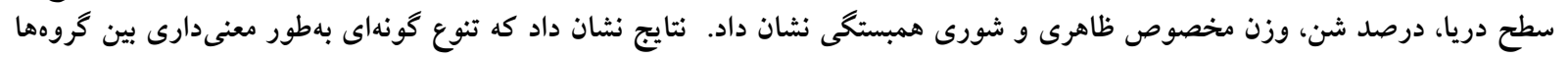

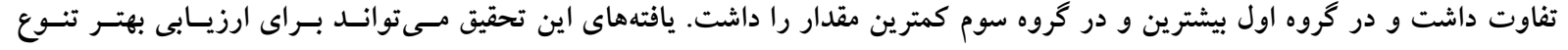

$$
\text { كونهاى و مديريت تنوع زيستى استفاده شود. }
$$

وازمهاى كليدى: گونههاى گياهى، رستهبندى، غنا، خوزستان

\footnotetext{
ا. كروه علوم محيط زيست، واحد اهواز، دانشكاه آزاد اسلامى، اهواز، ايران

r. كُوه علوم جنكل، دانشكده كشاورزى، دانشخاه ايلام، ايلام

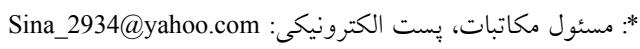


درختجهاى در گروههاى اكولوزيك مختلف متغير اسـت و ايسن

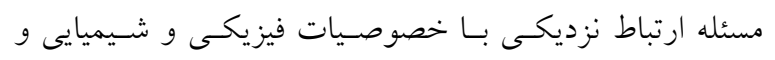

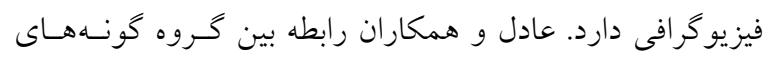

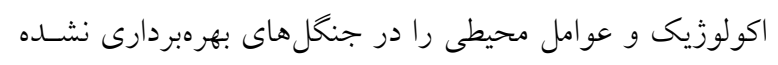

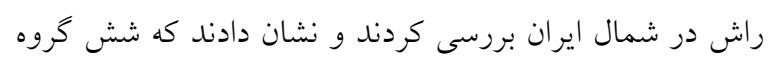

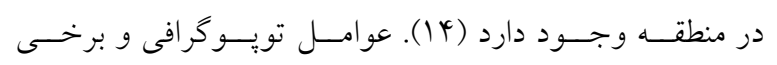
خصوصيات خاك مانند نيتروزن، فسفر و يتاسـيم از مهـم تـرين

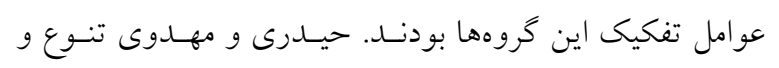

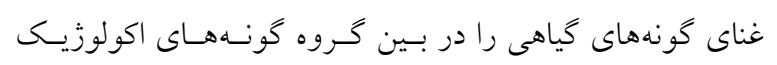

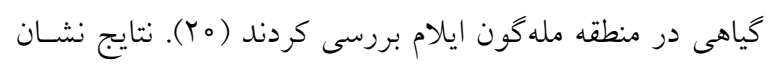

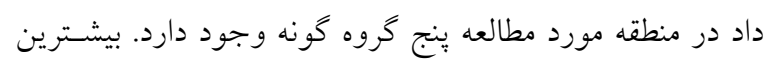

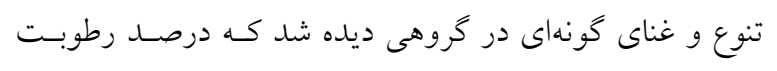

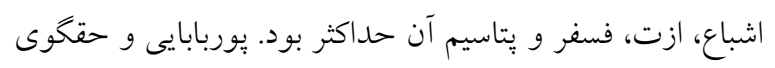

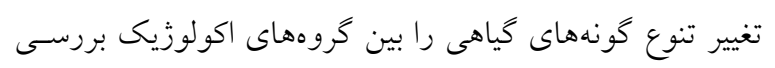

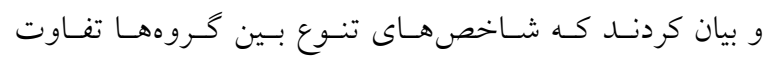

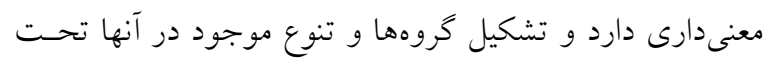

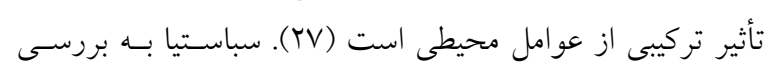

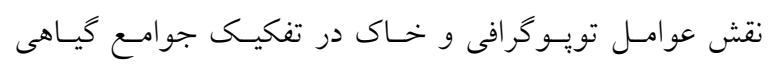

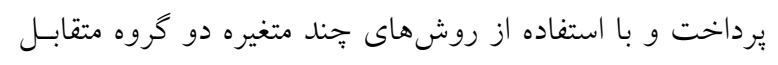

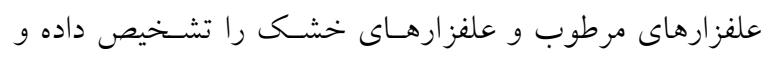

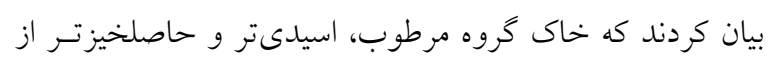
كروه خشك است (Yq).

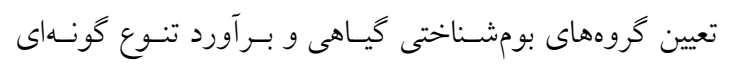

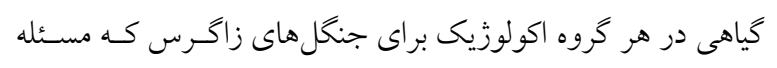

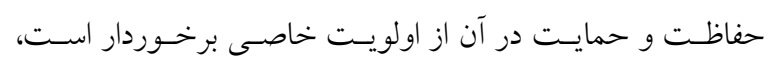

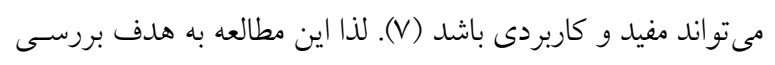

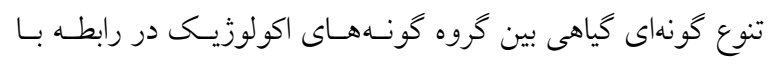
عوامل محيطى در بخشى از جنگل هاى زاكرس جنوبى انجام شد.

\section{مواد و روشها منطقه مورد مطالعه}

اين مطالعه در منطقه جنكلى امامزاده عبدالله شهرستان باغملـى مولى منهل

\section{مقدمه}

در اكوسيستمهاى جنكلى بـين كياهـان و سـاير قسـمتهـاى آن

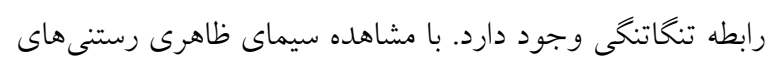

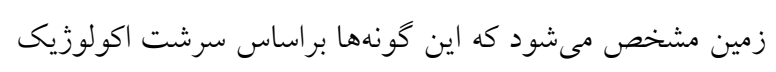

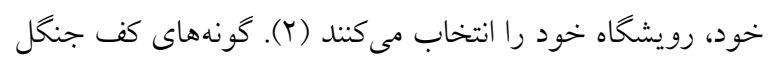

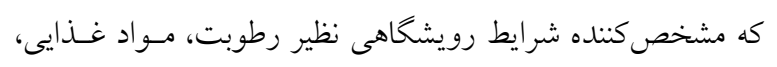

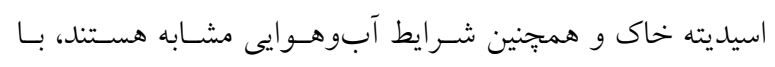

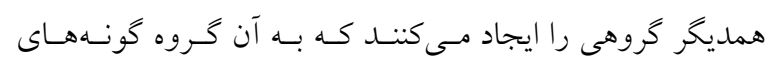

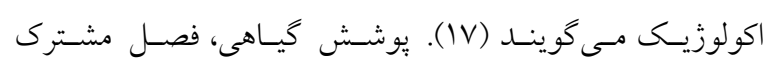

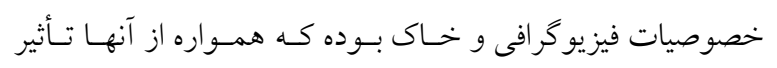

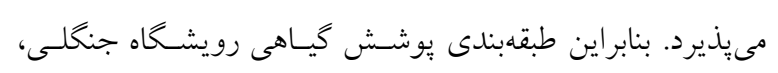

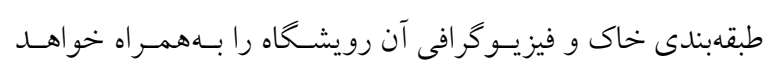

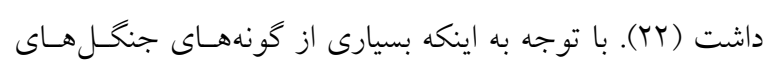

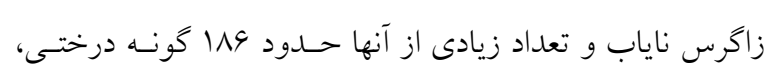

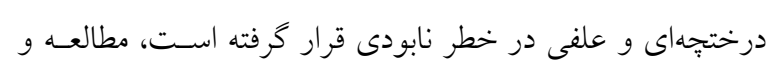

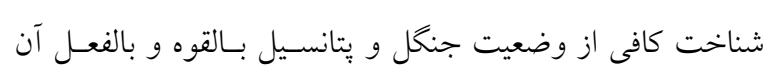
بهمنظور برنامهريزى صحيح، ضرورى بهنظر مىرسد كه متأسـفانه

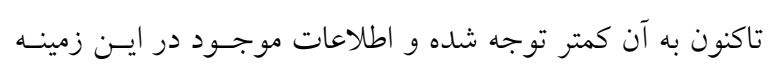

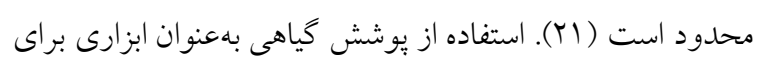

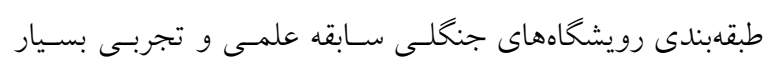

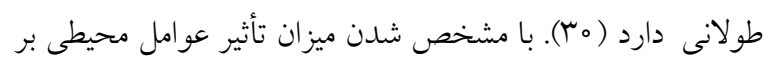

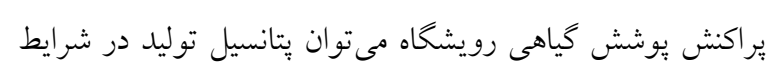

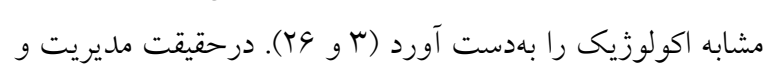
برنامهريزى دقيق طرحهاى حفاظتى و اجرايى در جنخـل نيازمنـد

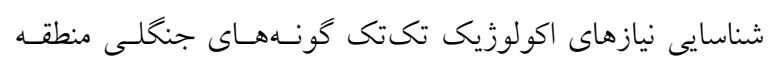

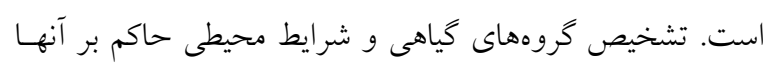

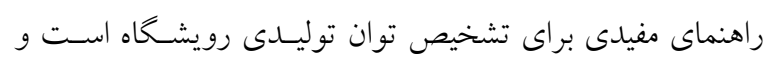

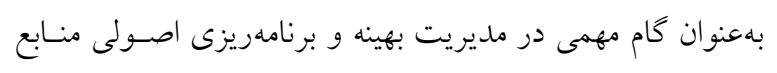
طبيعى تلقى مى نود (10).

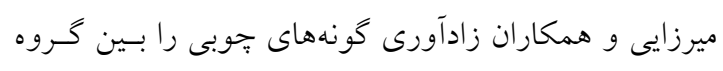

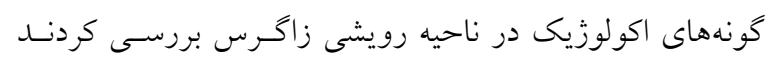

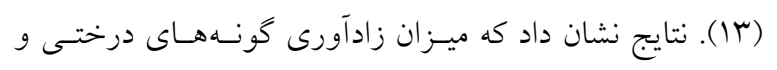



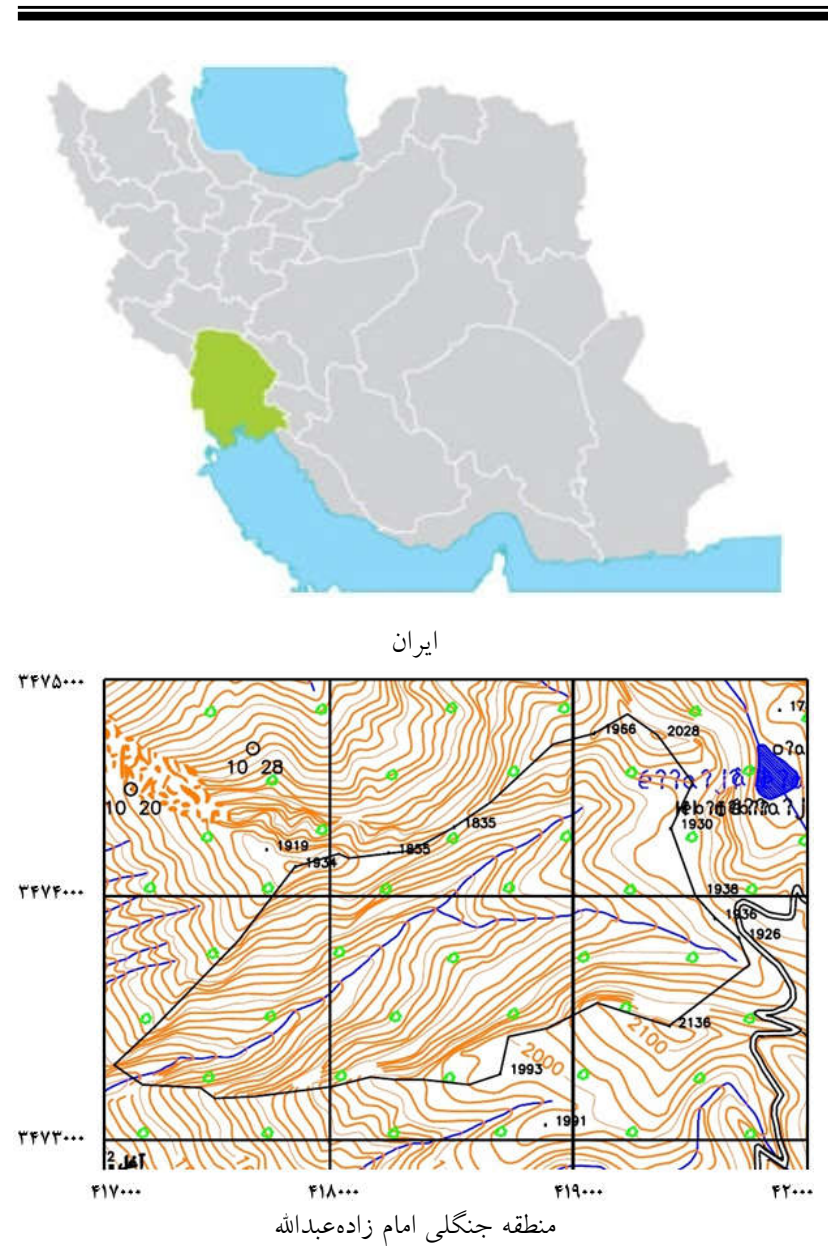

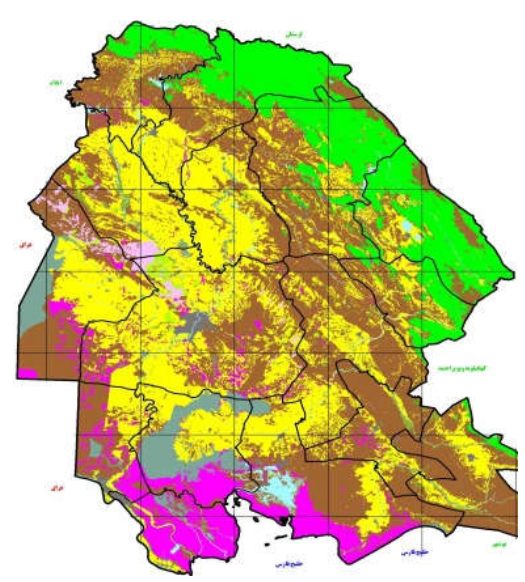

استان خوزستان

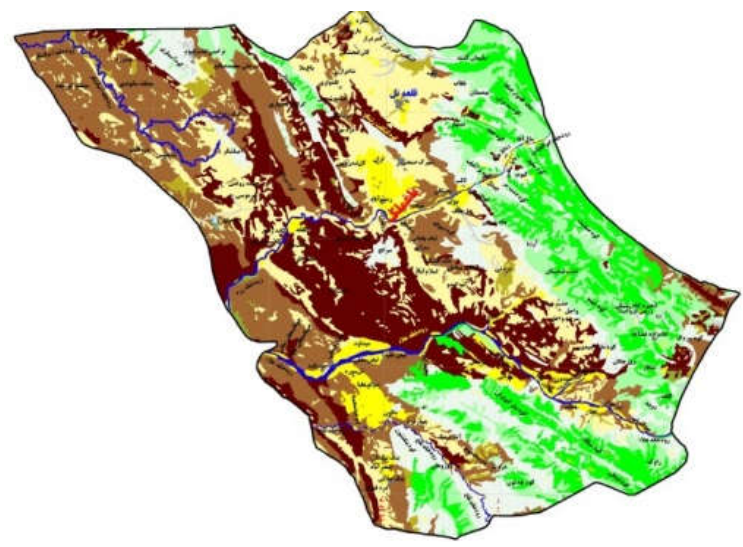

شهرستان باغملك

شكل 1. نقشه منطقه مورد مطالعه (رنخى در نسخه الكترونيكى)

برداشت دادهها

يّ از تعيين سطح قطعه نمونه بـهروش بـالاتهـاى حلزونسى، از

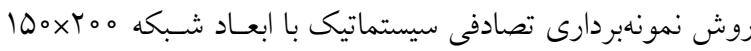

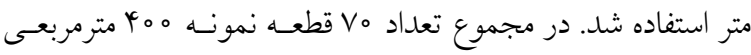

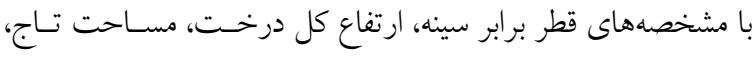

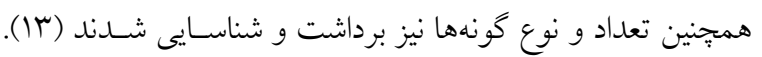

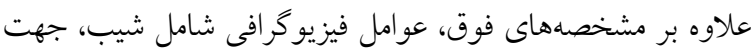

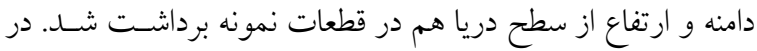

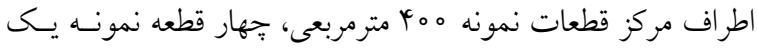
مترمربعى بلصورت تصادفى بهمنظور برداشت يوشش علفسى ييـاده

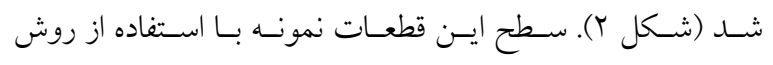

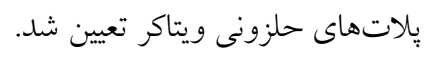

واقع در استان خوزستان به مساحت و Y هكتـار بـا مختصـات "D

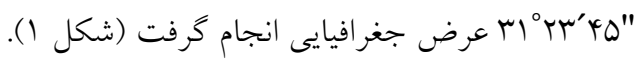
بلطور كلى اين منطقه از نظر شكل زمين كوهستانى و داراى

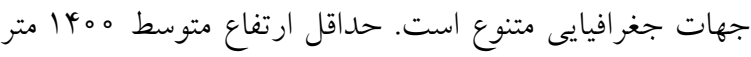

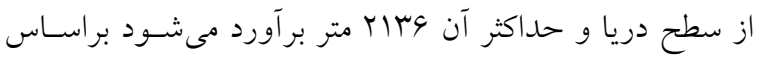

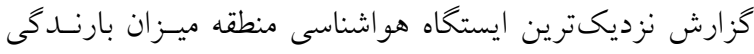

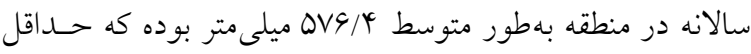

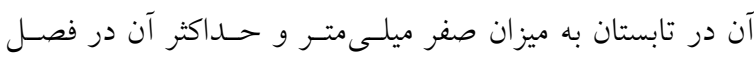

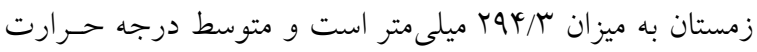

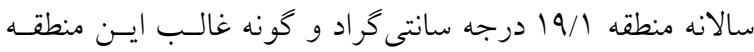
بلوط ايرانى (Quercus brantii) است. 
r.

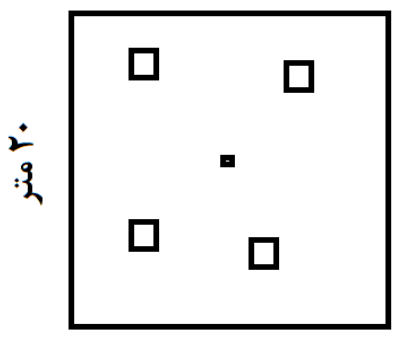

شكل r. روش بياده كرده قطعات نمونه (ه قطعات نمونه ا مترمربعى)

غناى كونهاى و R مطالعه تحليل خوشهاى بهمنظور كاهش عامل ذهنيت در كسته

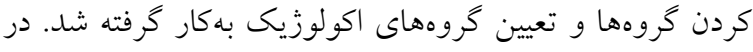

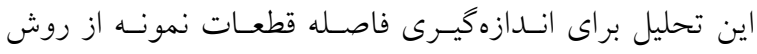

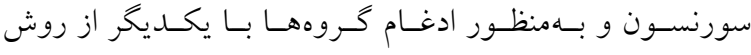
Flexible beta beta بهمنظور بررسى اختلاف گروهها از نظر تركيب كَاهى از آنـاليز (Multi-Response Permutation Procedures) MRPP شد. در اين تحليل با تلفيق معيار وفور نسبى و فراوانسى نسبى

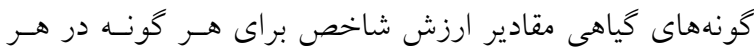

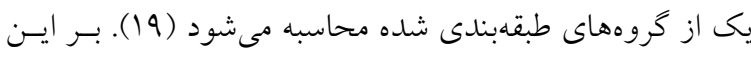

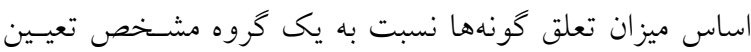

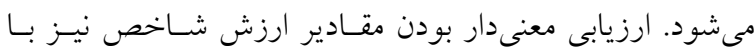

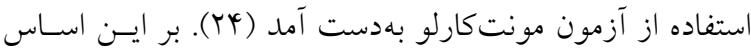

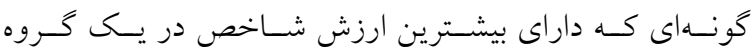

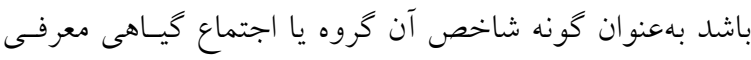

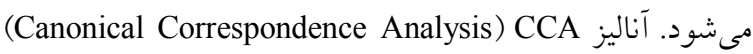
يا تجزيه و تحليل تطبيقى متعارف بهعنوان يكى انسيز از كارآمـدترين

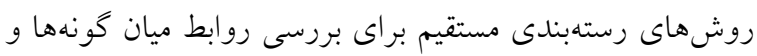

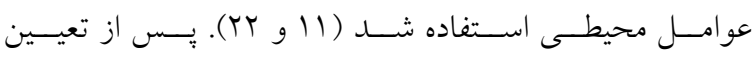

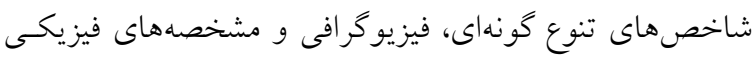

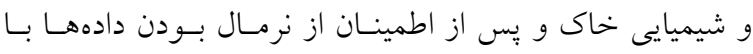

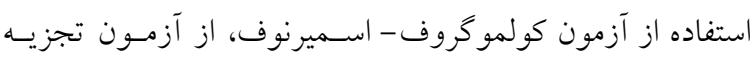

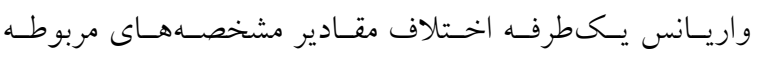

در هر قطعه نمونـه عـلاوه بــر تعـداد يـا يوشـش سطحى

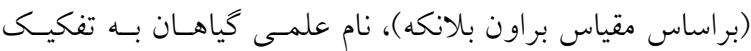

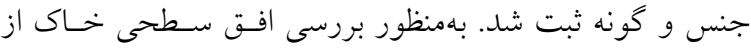

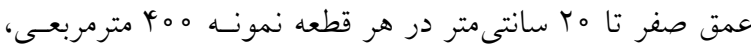

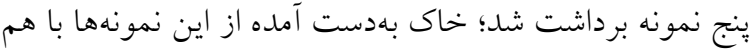

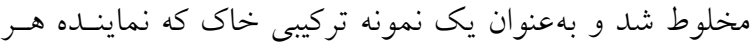

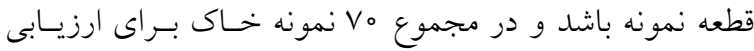
خصوصيات فيزيكى و شيميايى به آزمايشگاه منتقل شدند (TQ).

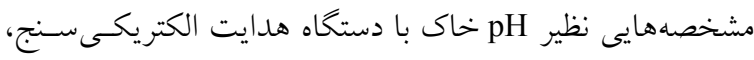

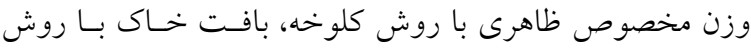
هيدرومترى بايكاس، فسفر قابل جذب با استفاده از روش اولسون، يتاسيم خاك بهروش استات، نيتروزن كل بهروش كجلدال، درصــ

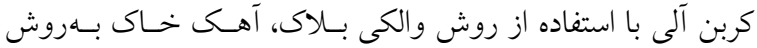

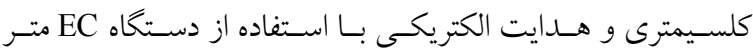

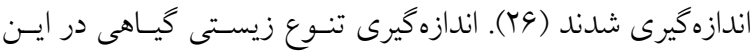

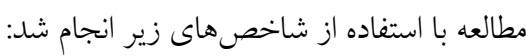

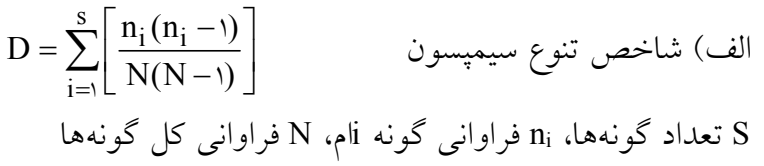
ب) شاخص تنوع شانون-وينر n فراوانى كل (مجموع فراوانى نسبى) و فراوانى نسبى هر كونه Evenness = تنوع شانون- وينر و S مقدار غناى كونهاى H $\mathrm{R}=\mathrm{S}$

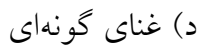




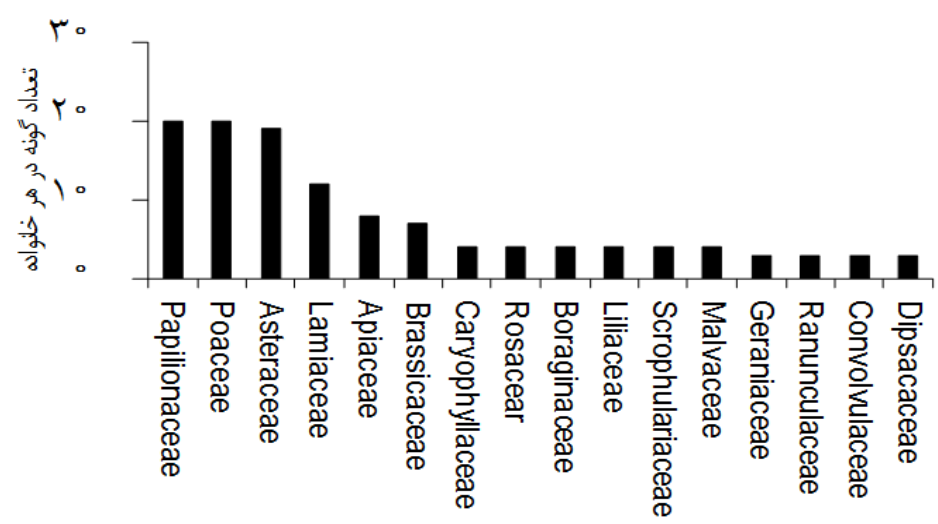

شكل r. فراوانى گونههاى متعلق به هر خانواده گياهى

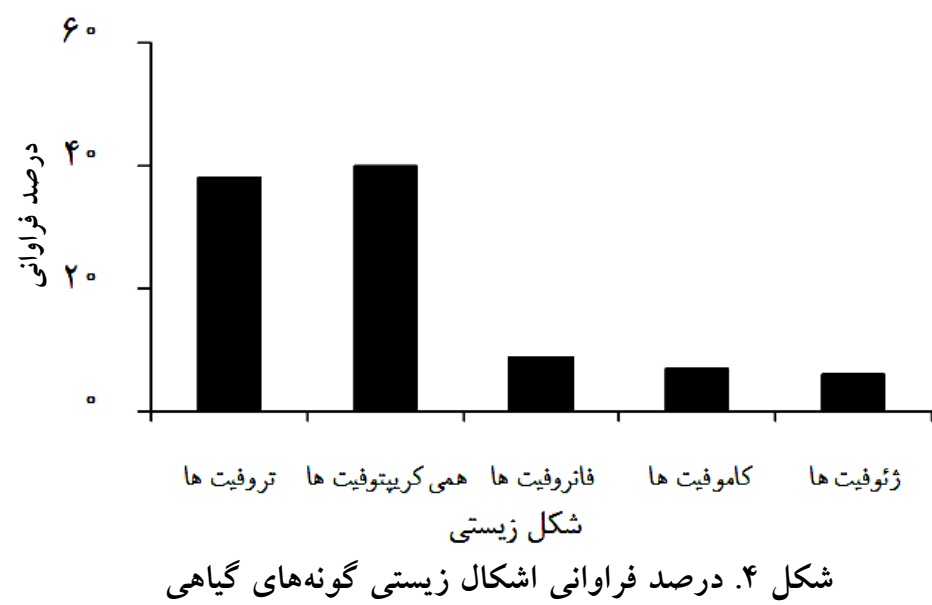

از كل كونهاى كياهى اين منطقه را شامل مىشوند (شـكل ب).

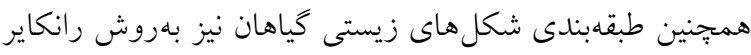

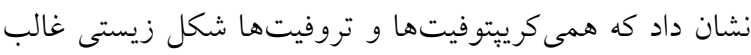
منطقه هستند (شكل (4).

دندروكرام حاصل از تجزيه و تحليل خوشهاى براساس حضور

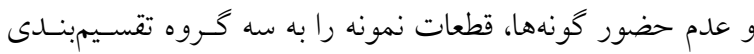

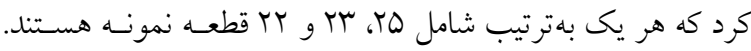

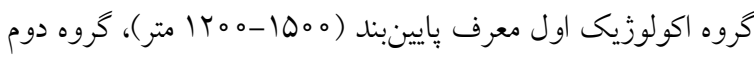

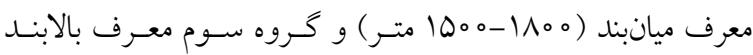

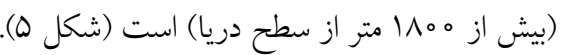

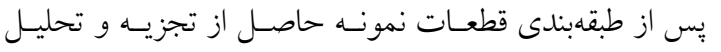

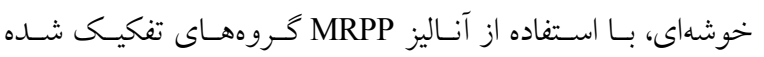

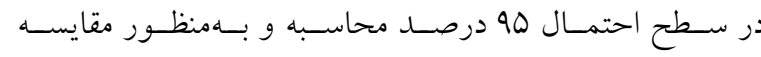

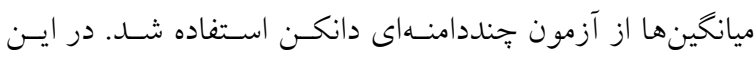

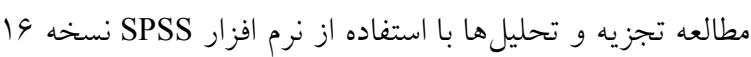

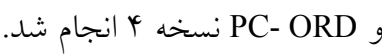
نتايج نتايج حاصل از بررسى نشان مىدهد در ايسن منطقـه تعـداد

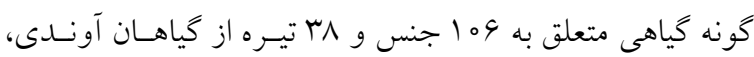

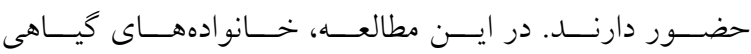
Asteraceae Paceae Prilionaceae

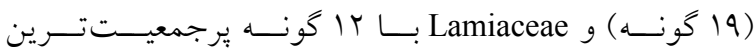

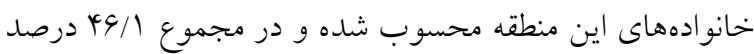


بومشناسى كاربردى/ سال هفتم / شماره دوم / تابستان IYV

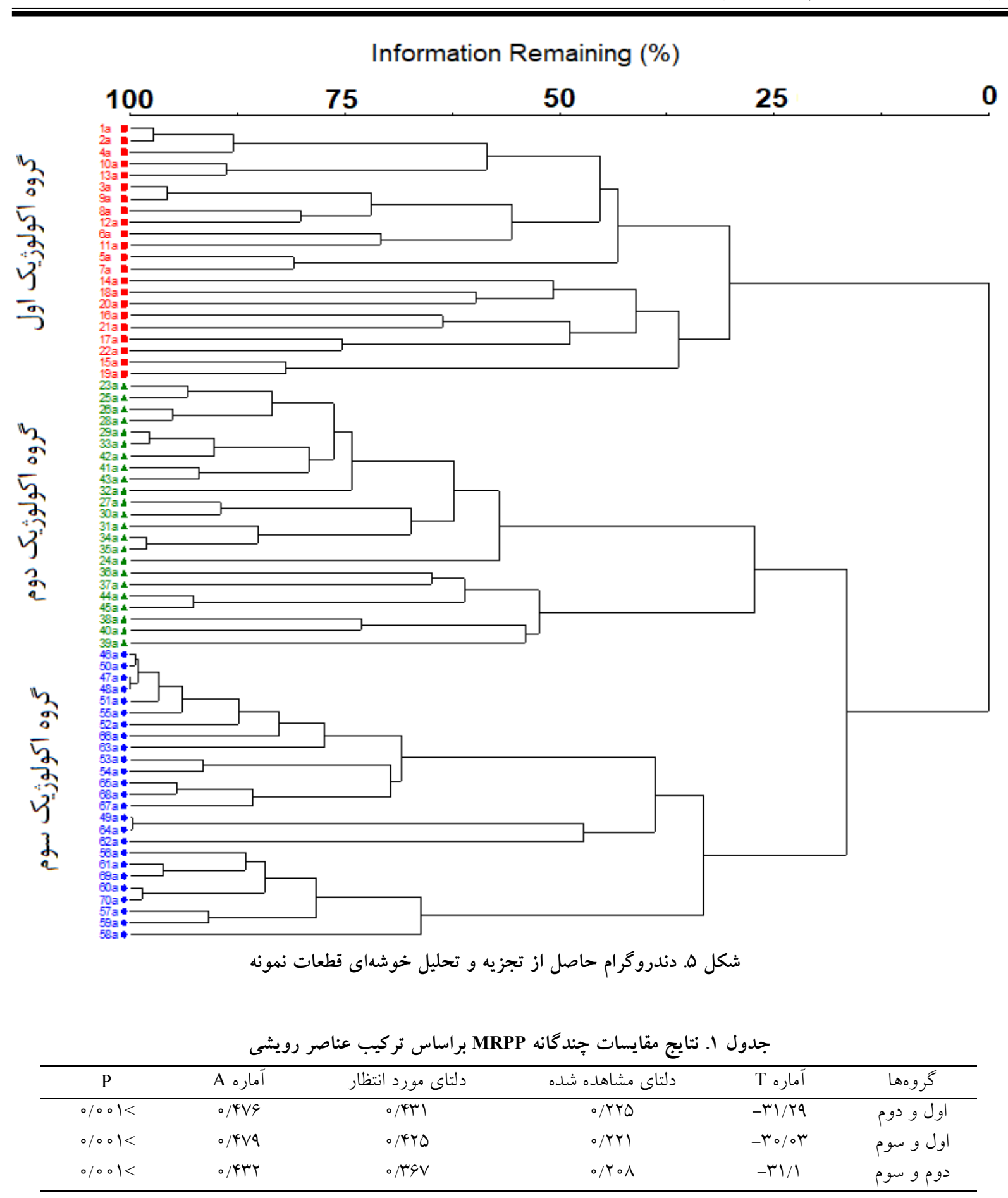

Aegilops و Hordeumbulbosum Agropyromtrichophorum triuncialis

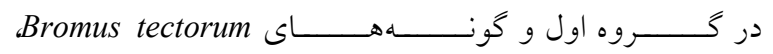
Bromus danthonia و Salvia macrosiphon
بهصورت جفتى براساس تركيب گياهى مـورد آزمـون قـرار گرفتنـــ (جدول (). اين تحليل نيز صحت تفكيك گروههاى سه كانه را تأييـد كرد. بـر اسـاس تجزيسه تحليـل گونسهــاى معـرف، گونـههـاى 


\begin{tabular}{|c|c|c|c|c|c|}
\hline \multicolumn{6}{|c|}{ جدول r. گونههاى شاخص گروه گونههاى اكولوزيك } \\
\hline رديف & كونههاى كياهى & كروه & كروف در دو هر & كروه & سَّح معنى دارى \\
\hline 1 & Agropyron trichophorum & 90 & 1 & $r$ & $0 / 001$ \\
\hline r & Artemisia aucheri & $\bar{r}$ & r & 99 & $0 / 001$ \\
\hline r & Artemisia haussknechtii & 1 & 。 & $\overline{9 V}$ & $0 / 001$ \\
\hline$r$ & Astragalus fasciculifolius & r & 。 & $\overline{91}$ & $0 / 001$ \\
\hline 0 & Astragalus adscendens & r & 1 & VQ & $0 / 001$ \\
\hline 4 & Astragalus gossypinus & $\circ$ & $\circ$ & 91 & $0 / 001$ \\
\hline V & Astragalus sieberi & $\wedge$ & 4 & 90 & $0 / 001$ \\
\hline$\wedge$ & Bromus danthonia & r & 94 & 1 & $0 / 001$ \\
\hline 9 & Bromus tectorum & 1 & $\overline{91}$ & 1 & $0 / 001$ \\
\hline 10 & Campanula cecilii & 。 & $\overline{r q}$ & 1 & $0 / 004$ \\
\hline 11 & Campanula perpusilla & 。 & $\overline{90}$ & ro & $0 / 009$ \\
\hline ir & Centaurea pabotii & 。 & rt & V & o/o०r \\
\hline ir & Gundelia tournefortii & 0 & $\overline{9 r}$ & r & $0 / 001$ \\
\hline 14 & Hordeum bulbosum & 91 & $\overline{1}$ & 。 & $0 / 009$ \\
\hline 10 & Nepeta persica & - & ro & r & \\
\hline 19 & Phlomis persica & 1 & 1 & 90 & $0 / 001$ \\
\hline iv & Pistacia atlantica & 01 & ir & ir & $0 / 009$ \\
\hline 11 & Pterocephalus brevis & $\circ$ & $\circ$ & 11 & $0 / 009$ \\
\hline 19 & Quercus brantii & r & re & $\overline{r Q}$ & $\circ / 0 \circ Y$ \\
\hline ro & Rhamnus persica & $\overline{r o}$ & 4 & r & ०/O० \\
\hline rI & Salvia macrosiphon & $\overline{1}$ & 90 & 1 & $0 / 001$ \\
\hline rt & Stachys lavandulifolia & $\circ$ & $\bar{\circ}$ & 11 & $0 / 004$ \\
\hline r & Acer monspessulanum & $\circ$ & 1 & $\overline{\Delta r}$ & $0 / 001$ \\
\hline re & Anthemis persica & 1 & $\underline{r v}$ & $r$ & $0 / 001$ \\
\hline ro & Astragalus cephalanthus & r & $\overline{1}$ & $\Lambda \circ$ & $0 / 001$ \\
\hline rG & Festuca ovina & r & ry & $\bar{\circ}$ & $\circ / \circ \circ \mathrm{V}$ \\
\hline rV & Crataegus azarolus & r & 4 & $\Lambda 9$ & $0 / 001$ \\
\hline rی & Aegilops triuncialis & 94 & 1 & $\bar{r}$ & $0 / 001$ \\
\hline
\end{tabular}

حداكثر ارزش معرف هر گونه از لحاظ آمارى با روش مونتكـارلو مورد آزمون قرار كرفت كه نتايج اين آزمون در سطح يـك درصـد معنى دار بودن حداكثر ارزش معرف گونهها را نشان داد (جدول Y). روابط بين عوامل محيطى و بوشش گياهى با استفاده از آنـاليز

CCA بررسى شـد. در ايـن آنـاليز از محورهـاى اول و دوم CCA

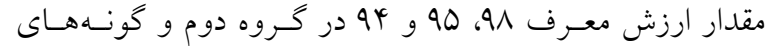
persica Astragalus gossypinus Artemisia haussknechtii Artemisia aucheri و بهترتيب با مقـدار ارزش معسرف

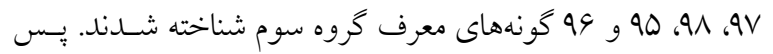
از محاسبه ارزش معرف گونههاى گياهى در گـروههـاى مختلـف، 


\begin{tabular}{|c|c|c|}
\hline \multicolumn{3}{|c|}{ جدول r. نتايج همبستخى بيرسون بين مشخصه هاى محيطى و محورهاى اول و دوم CCA } \\
\hline محور دوم & محور اول & متغير هاى محيطى \\
\hline$-\circ / \backslash \wedge \varphi \mathrm{ns}$ & $\circ / 499^{*}$ & اسيديته (1:1 H (1:) \\
\hline$-0 /$ TqY ns & $-0 / 14 q^{* *}$ & هدايت الكتريكى (dsm/m) \\
\hline$\circ / \Delta \Delta r^{*}$ & $\circ / \mathrm{V} F \psi^{* *}$ & رطوبت اشباع (درصد) \\
\hline$\circ / \pi$ \% & $\circ / 190^{* *}$ & رس (درصد) \\
\hline$-0 / 1 Y G \mathrm{~ns}$ & $-\circ / V^{4} \Lambda^{* *}$ & شن (درصد) \\
\hline$-0 / Y \circ r_{n s}$ & - / TMQ ns & سيلت (درصد) \\
\hline$\circ / /\left.\right|^{\mathrm{Ans}}$ & $-0 / 9 \mu V^{* *}$ & وزن مخصوص ظاهرى ( ${ }^{-3}$ (gr cm $^{-3}$ \\
\hline$\circ / 0 \varphi^{n}$ ns & $\circ /\left.\wedge \cdot\right|^{* *}$ & كربن آلى (درصد) \\
\hline$\circ / 09^{n s}$ & $0 / \Lambda \mu y^{* *}$ & نيتروزن كل (درصد) \\
\hline$-0 / 1 / \mu_{n s}$ & $0 / 9 r^{* *}$ & يتاسيم كل (mg kg-1) \\
\hline o/Art* & $\circ / \Lambda \circ D^{* *}$ & فسفر كل (mg kg-1) \\
\hline$-\circ / \circ \wedge \mathrm{ns}$ & $0 / 9 \Lambda \Lambda^{* *}$ & ظرفيت تبادل كاتيونى (cmol/kg) \\
\hline o/lkY ns & $-0 / 911^{* *}$ & ارتفاع از سطح دريا (متر) \\
\hline$\circ / T \Delta 9$ & O/KTI & مقادير ويزه \\
\hline $1 \% / r$ & $V Y / 4$ & درصد تبيين واريانس \\
\hline
\end{tabular}

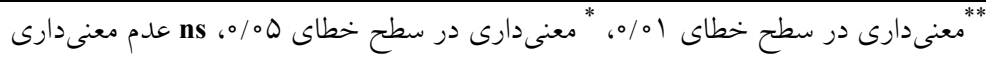

مشخصههـاى درصـد مـاده آلى، رس، يتاسـيم، فسـفر و ازت كل از جمله مهم تـرين عوامـل در تشـكيل ايسن خـروه هسـتند. و كونــهـهـ Salvia macrosiphon Bromus tectorum Bromus danthonia اكولوزيك محسوب مى شوند. گروه سوم در نقطه مقابـل گـروه اول و دوم قـرار كرفتـه اسـت. ايسن خـروه كـه بيشـتر قطعـات

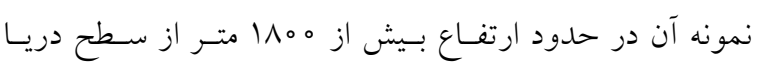

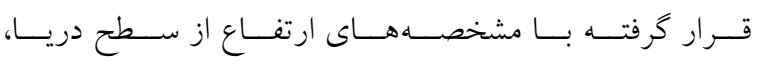
هـدايت الكتريكسى، وزن مخصــوص ظــاهرى و درصـــ شـن

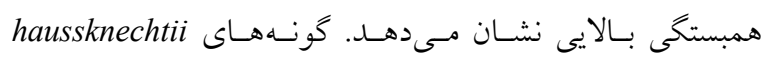
و persica Phlomis،Astragalus gossypinus Artemisia Artemisia aucheri

$$
\text { مى شوند. }
$$

نتايج آزمون تجزيه واريانس يكىطرفه (ANOVA) نشان داد كه بين كروهها از نظر اسيديته، شورى، رطوبت اشـباع، درصــ
بهدليل دارا بودن بالاترين مقدار ويزه بهترتيب ابس/ه و وMOY/

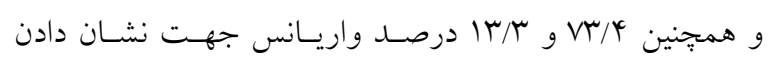
همبستخى استفاده شد (جدول ب). رستهبندى گونههـاى گيـاهى

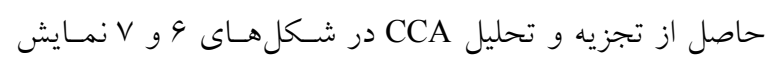
داده شده است. تحليل همبستخى انجام شده نشـان داد بـيش از

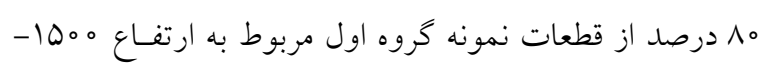

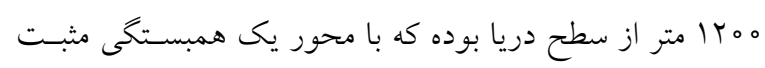
دارد. اسديته، ازت كل، ظرفيت تبادل كاتيونى، درصد ماده آلى و رس بالا مهم ترين خصوصيات ادافيكى در تشـكيل ايسن خـروه

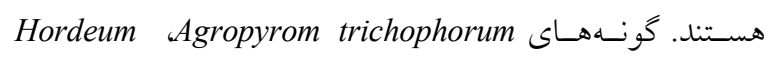
Aegilops triuncialis و از جمله كونههـاى كيـاهى

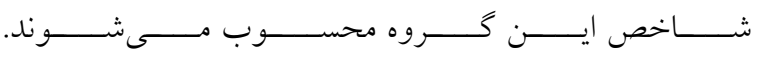
گروه دوم در بالاى گروه اول قرار گرفته و با محـور اول و دوم

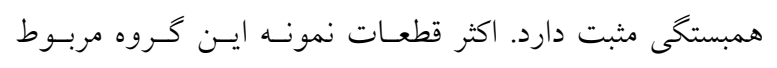

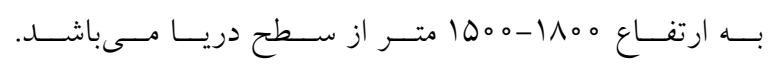




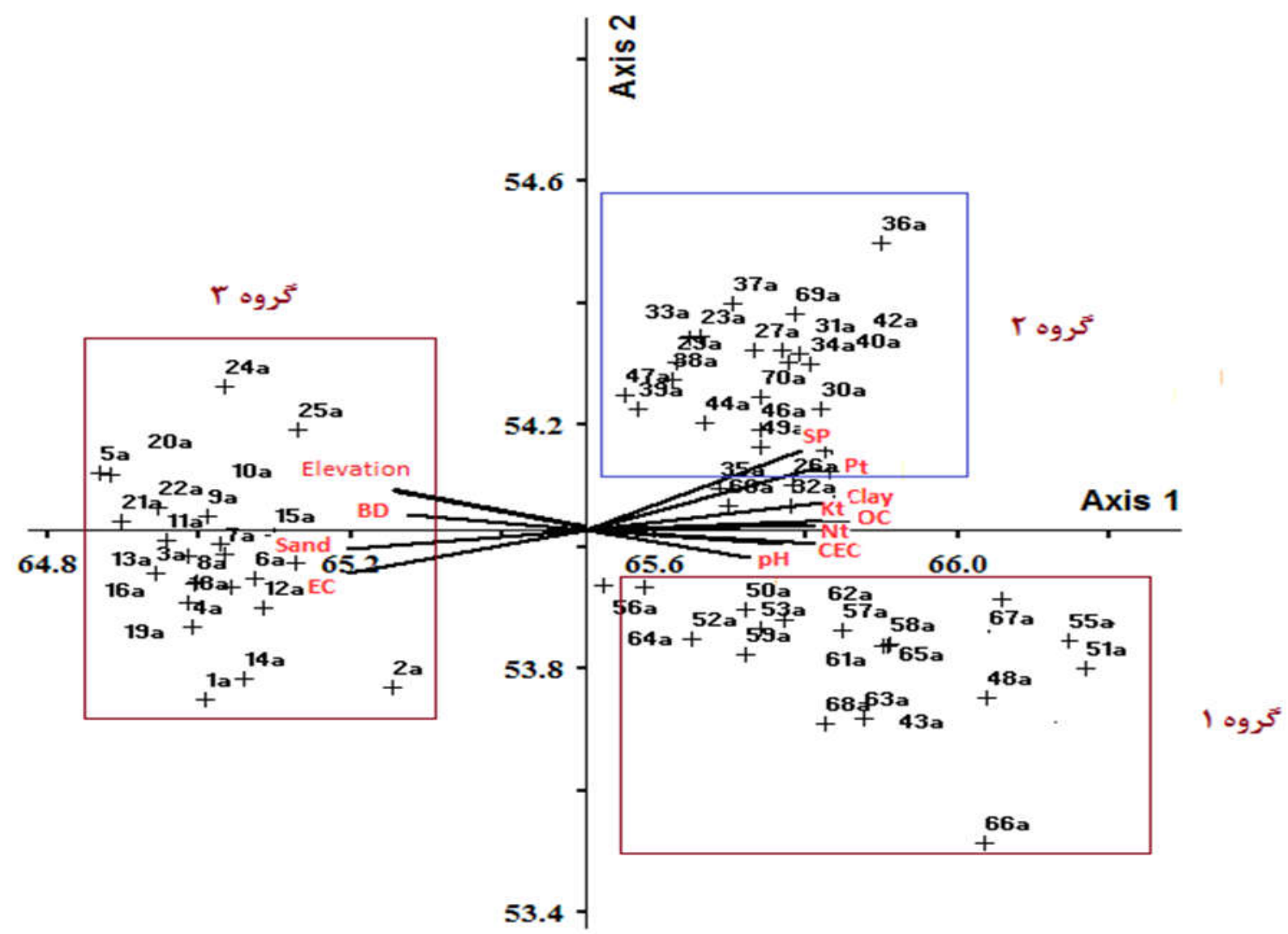

شكل 9. رستهبندى قطعات نمونه حاصل از تجزيه و تحليل SP) CCA: درصد رطوبت اشباع، PH: اسيديته، Pt: فسفر كل،

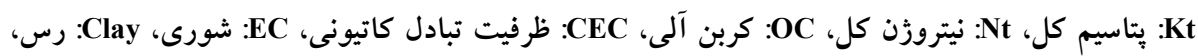

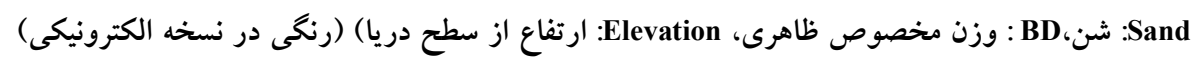

كونهاى اكولوزيك تشكيل شده براورد شـد. نتـايج آنـاليز تجزيـه

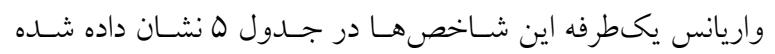

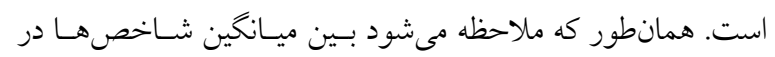

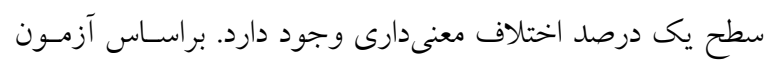

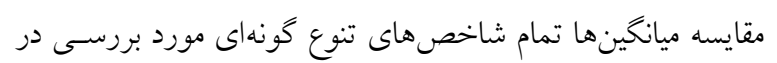

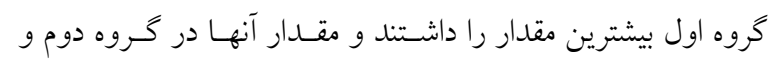
سوم كاهش معنى دارى داشت. لازم به ذكر است كه يكنواختى بـين ودين كروه دوم و سوم اختلاف معنىدارى نداشت (جدول ها ه).

بحث

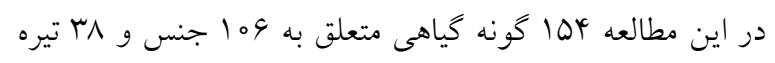

رس، سيلت و شن، وزن مخصوص ظاهرى، درصد كربن آلى،

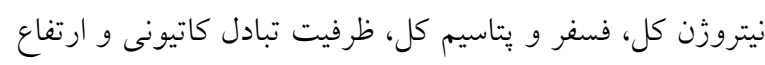

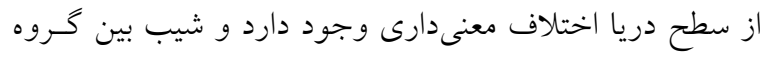

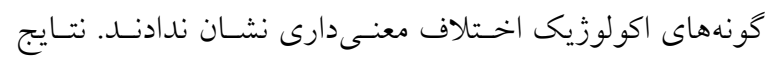

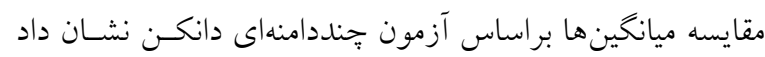

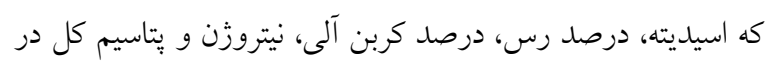

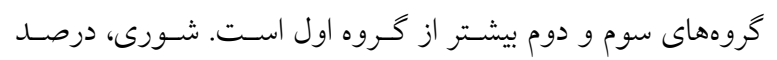

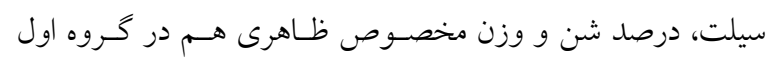

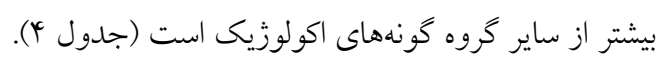

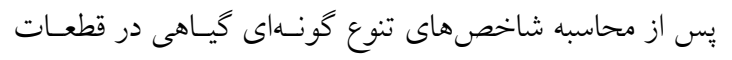

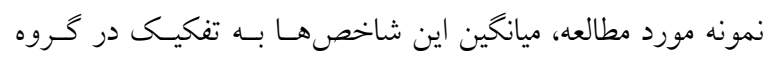




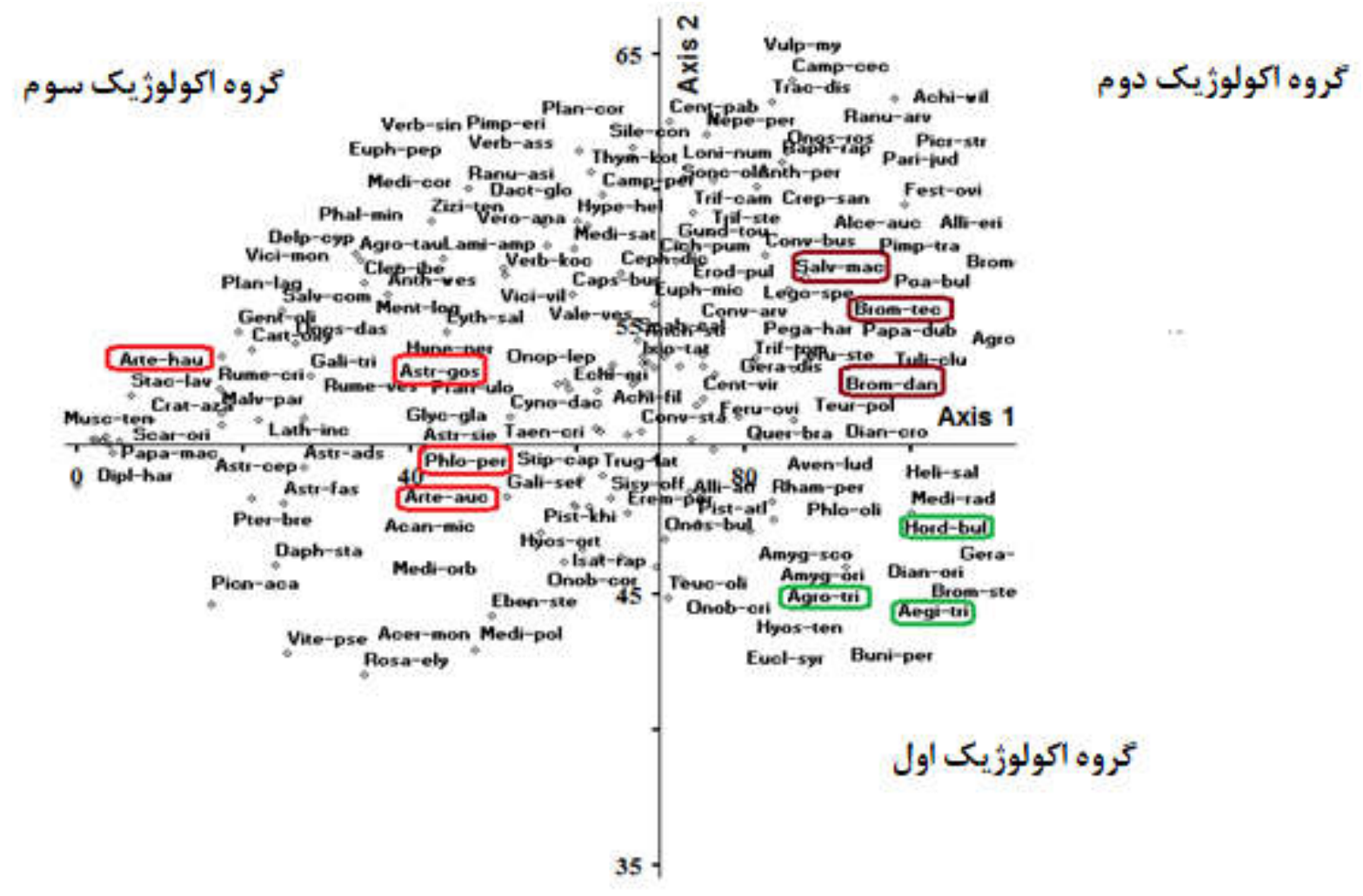

شكل V. رستهبندى گونههاى گياهى حاصل از تجزيه و تحليل CCA (رنخى در نسخه الكترونيكى)

جدول F. مقايسه ميانكين متغيرهاى محيطى بين كروه كونهاى اكولوزيك براساس آزمون دانكن

\begin{tabular}{|c|c|c|c|c|}
\hline \multirow{2}{*}{ سطح معنى دارى } & كُروه اكولوزيك r & كروه اكولوزيك r & كروه اكولوزيك 1 & \multirow{2}{*}{ متغيرها } \\
\hline & & ميانخين 土 اشتباه معيار & & \\
\hline $0 / 000$ & $V / \mathscr{A r}\left( \pm \circ / \circ r^{\mu}\right) a$ & $V / A r\left( \pm \circ / \circ r^{2}\right) b$ & $V / T M( \pm 0 / 01)^{c}$ & اسيديته (1:1 H (1:1 ) \\
\hline$\circ / 0 \circ 0^{* *}$ & $0 / T q( \pm 0 / 0 r)^{c}$ & $0 / \pi \varphi( \pm 0 / 01) b$ & $\circ / 19( \pm 0 / 01)^{a}$ & شورى (dS m \\
\hline $0 / 001^{* *}$ & $r q / 91( \pm r) b$ & $90 / 91( \pm 1 / \pi)^{a}$ & $r \wedge( \pm \circ / \Lambda)^{c}$ & رطوبت اشباع (\%) \\
\hline ०/००ץ ${ }^{* *}$ & $r V / r( \pm 0 / V)^{a}$ & $r q \pm(0 / 9)^{a}$ & $\mid \Lambda / \Gamma( \pm 1 / T)^{b}$ & رس (\%) \\
\hline ०/० ${ }^{*}$ & $M y / q( \pm 0 / V)^{b}$ & $\mathrm{HY} / \mathrm{V} \pm(0 / 9)^{\mathrm{b}}$ & $\mathrm{r}( \pm 1 / Y)^{\mathrm{a}}$ & سيلت (.) - ) \\
\hline$\circ / 0 \circ 0^{* \pi}$ & $r V / V( \pm 0 / 9)^{b}$ & $r \varphi / T I \pm(\circ / 9)^{b}$ & $F r / D F( \pm 1 / 4)^{a}$ & 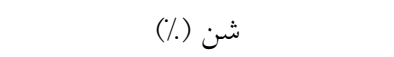 \\
\hline $0 / 0 \circ \psi^{* *}$ & $1 / 4( \pm 0 / 01)^{c}$ & $1 / 9( \pm 0 / 0 Y)^{b}$ & $1 / 9( \pm / \circ 4)^{a}$ & وزن مخصوص ظاهرى (g cm-3) \\
\hline $0 / 001^{* *}$ & $r / Q( \pm 0 / 1)^{a}$ & $r / \mu_{ \pm}(\circ / \circ r)^{b}$ & $1 / \Gamma( \pm 0 / 0 \%)^{c}$ & ماده آلى (\%) \\
\hline$\circ / 0 \circ 0^{* *}$ & $r / 4( \pm 0 / 11)^{a}$ & $r / 9( \pm \circ / \circ \Delta)^{b}$ & $\circ / 1 r( \pm 0 / 09)^{c}$ & 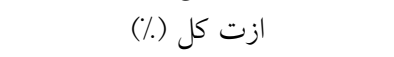 \\
\hline $0 / 001^{* *}$ & $\Delta Q \psi / \backslash Q( \pm 1 \circ)^{b}$ & $\varphi \circ \Delta / T^{\mu}( \pm \varphi)^{a}$ & $r V I / r( \pm 0 / 9)^{c}$ & فسفر كل (mg kg-1) \\
\hline$\circ / 0 \circ 0^{* *}$ & $\mu \circ \Delta( \pm V Q)^{a}$ & $r \mid \Lambda N / I r( \pm V \Psi)^{\text {a }}$ & $Y|V 0 / I|( \pm F \mid)^{b}$ & يتاسيم كل (mg kg-1) \\
\hline$\circ / 000^{* *}$ & $T / T( \pm 0 / 9)^{c}$ & $1 / \wedge( \pm \circ / 9)^{b}$ & $1 / 4( \pm 0 / 9)^{a}$ & ظرفيت تبادل كاتيونى (cmol kg $\left.{ }^{-1}\right)$ \\
\hline$\circ / r \mathrm{~ns}$ & $09( \pm Y)^{c}$ & $9 \circ( \pm V)$ & $9 r( \pm \Delta)$ & شيب (\%) \\
\hline$\circ / \circ \circ 0^{* *}$ & $1 \wedge r \circ( \pm r 90)$ & $19 V \circ( \pm 1 M \Lambda)$ & $149 \circ( \pm 190)$ & ارتفاع از سطح دريا (متر) \\
\hline
\end{tabular}


ارزيابى تنوع گونهاى گياهى زيراشكوب بين گروههاى اكولوزيك در ارتباط ....

\begin{tabular}{|c|c|c|c|c|c|}
\hline سطح معنىدارى & $\mathrm{F}$ & ميانخين مربعات & مجموع مربعات & $\mathrm{df}$ & شاخص تنوع \\
\hline $0 / 001$ ** & $109 / V 9$ & $\circ / 0 D G$ &.$/ 11$ & r & تنوع سيمِسون \\
\hline$\circ / \circ \circ Y^{* *}$ & TVN/rG & $r / r q V$ & $\Lambda / v q$ & r & تنوع شانون- وينر \\
\hline \%०००*** & $144 / 99$ & .040 & $0 / 09$ & r & يكنو اختى - شانون وينر \\
\hline $0 / 001^{* *}$ & $114 / \pi$ & $r \Delta \circ r / \Delta r$ & $0 \circ \circ V / \circ \Lambda$ & r & غناى گونهاى \\
\hline
\end{tabular}

جدول 9. نتايج مقايسه ميانكين شاخصهاى تنوع گونهاى گياهى براساس آزمون دانكن (ميانخين土 اشتباه معيار)

\begin{tabular}{|c|c|c|c|}
\hline كروه سوم & كروه دوم & كروه اول & شاخص تنوع \\
\hline$\circ / 01 \pm 0 / \circ r^{c}$ & $0 / 99 \pm 0 / 09 \mathrm{~b}$ & $\circ / \vee \wedge \pm \circ / \circ \vee a$ & تنوع سيمِسون \\
\hline $\mid / 01 \pm 0 / 1 \mu^{c}$ & $r / l \pm \circ / l V^{b}$ & $r / 9 \pm \circ / r_{\circ} a$ & تنوع شانون- وينر \\
\hline$\circ / 4 a \pm \circ / \circ \varphi^{b}$ & $\circ / 01 \pm \circ / \circ \Delta^{b}$ & $. / 91 \pm 0 / 04$ a & يكنو اختى - شانون وينر \\
\hline$r T \pm Y / T_{c}$ & $\varphi \circ \pm V / \mathcal{C} b$ & $\Delta r \pm 9 / V$ a & غناى گونهاى \\
\hline
\end{tabular}

حروف متفاوت نشاندهنده وجود اختلاف معنىدار است.

كونههاى معرف به همراه آزمون مونت كارلو مىتواند بـهـنـوان يك روش كمى مناسب براى انتخاب تعـداد بهينـه گـروههــا در روش هاى مختلف طبقـهبنـدى رويشـخاه بـهــار كرفتـه شـود.

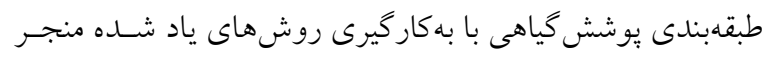
به تفكيك سه كروه اكولوزيك در منطقه مورد مطالعه مسى شـود. مناطق پيايينبند، ميانبند و بالابند هر كــام تشـكيل يـك گــروه اكولوزيك مجزا دادهاند. تجزيه و تحليل MRPP مشخص كـرد كه گرووهاى تشكيل شده از نظر تركيب عناصر رويشسى داراى

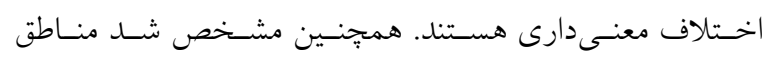
يايينبند و ميانبند نسبت به بالابند بهدليل بزرگتر بودن آماره در آنها داراى كمترين اختلاف بوده كه اين نتيجه دور از انتظـار نبود. اما مناطق يايينبند و بالابند نسـبت بـه ميـانبنـد بـهدليـل كو جكتر بودن آماره T در آنها داراى اختلاف بيشـترى هسـتند. اين مطلب بيانخر اين نكته است كه با افزايش ارتفاع در منطقـه

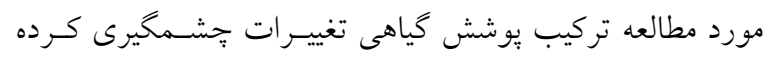
است و اين تغيير با طبقات ارتفاع از سـطح دريـا انطبـاق دارد. Hordeum bulbosum Agropyrom trichophorum
از كَاهان آوندى شناسايى شدند كه حضـور ايسن تعـداد گونـهـ

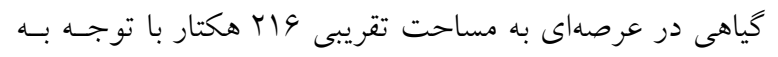

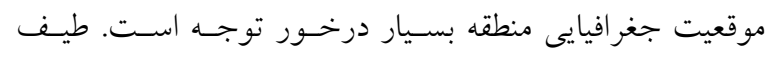
زيستى غالب منطقه نشانگر فلور تيبيك جنخلى است كـه در آن درصد حضور همىكرييتوفيتهـا بالاسـت (1). دليـل ايسن امـر ناشى از سيرى كردن فصل سرما توسط جوانههاى تجديدكنــده حيات در اين گياهان در سطح خاك و در ميـان لاشـبرگهـا و برفهاى زمستانى مى تواند باشد كـه بـا توجـهـ بـه شـروع زود

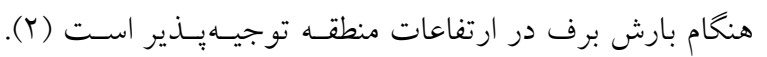

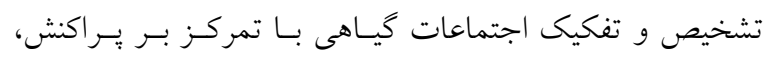
تركيب و طبقهبندى جوامع كياهى قلـب علـم يوشـش كيـاهى است (Y) (Y). همانطـور كـه در بخـش نتـايج تجزيسه و تحليـل خوشهاى ملاحظه شد، درصورتى كه سه گروه از قطعات نمونـه انتخـاب شـوند قطعـات نمونـهـ هـر خـروه از جهـت شـرايط فلورستيكى داراى بيشـترين شـباهت در بـين خــود و كمتـرين شباهت را نسبت به قطعات نمونه ساير گروهها خواهند داشت. نتايج اين تحقيـق نشـان مسىدهـد كـه روش تجزيسه و تحليـل 
است (^). متغير ارتفاع از سطح دريا بر براكنش بوشش گيـاهى

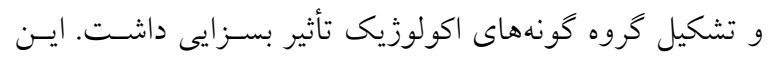

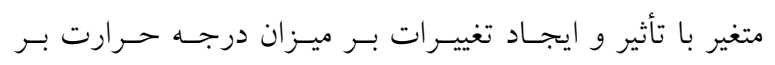

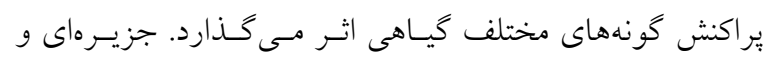

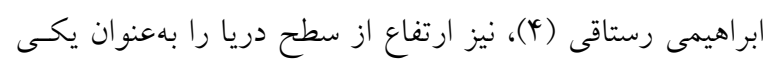

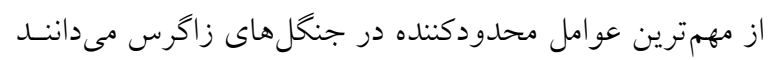

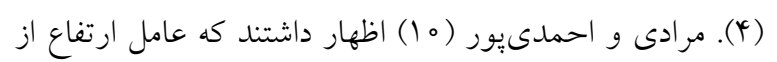

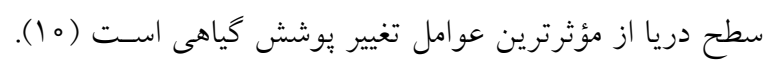
همجنين نتايج اين بزؤهش نشان داد كه شسيب روى تركيـب و براكنش گياهان تأثير زيـادى نداشـته اسـت، دليـل ايسن مسـئله

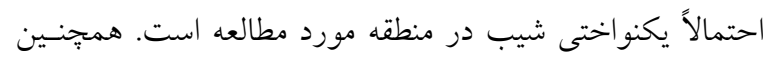

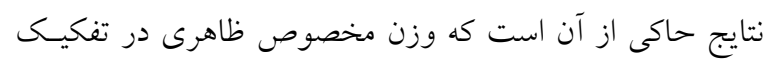
گروههاى گياهى و بيراكنش گونهها مؤثر است. باجتالا نشان داد كه وزن مخصوص ظاهرى بر ميزان رطوبـت خـاك و درنتيجـهـ يراكنش گونههاى گياهى مؤثر اسـت (91). نتـايج ايسن مطالعسه

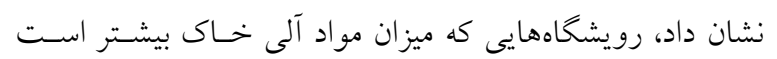

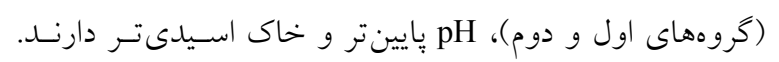
اسيديته از عوامل مهم در بر اكنش و استقرار جوامع گياهى است

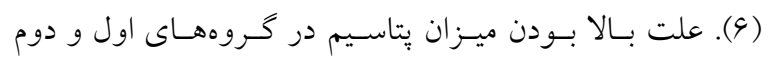

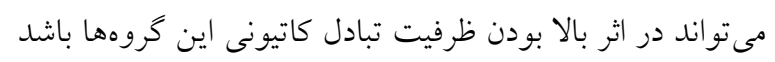

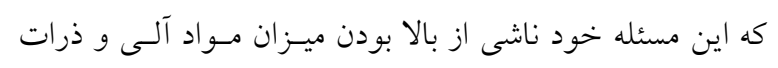
رس در خاك اين گروههـا اسـت. در مطالعـات مشـابه فسـفر، يتاسيم و نيتروزن از عو امل مهم در يــراكنش و تفكيـى جوامـع

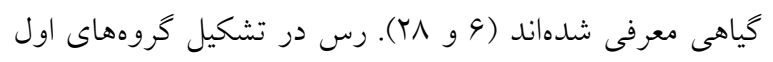
و دوم منطقه اثر مثبت داشـته اسـت. درحقيقـت، رس خــاك از طريق تشكيل كميلكسهاى آلى - معدنى و جذب سطحى مـواد هوموسى، مـاده آلى را در خـاك حفـظ مسى كنـــ (9). در كـل براساس نتايج مىتوان اذعان كرد كه تنوع كونهاى در گــروههــا بيشتر تحت تأثير غناى كونهاى بوده است. همجنـين يكنـواختى

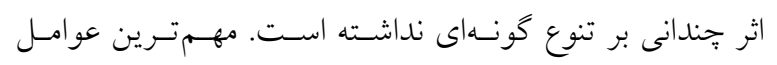

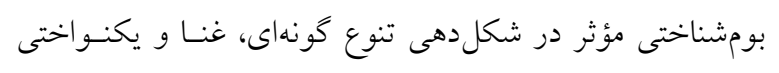

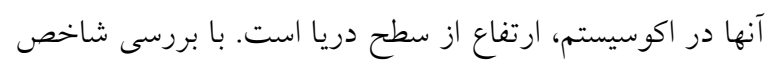

و Aegilops triuncialis از جملـه گونسهــاى گيـاهى شـاخص گروه اول محسوب مىشوند. گروه دوم در بالاى گروه اول قرار كرفته و با محور اول و دوم همبستخى مثبت دارد. اكثر قطعـات

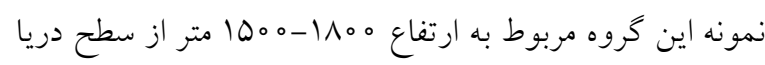
است. مشخصههاى درصد كـربن آلى، رس، يتاسـيم، فسـفر و

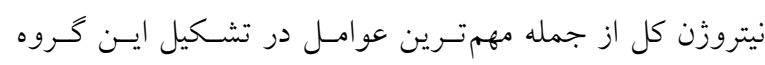

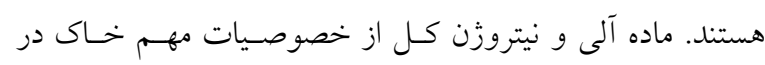

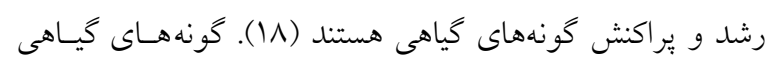
Bromus danthonia galvia macrosiphon Bromustectorum از جملـه كونسههـاى شـاخص خـروه اكولوزيـك دوم محسـوب مسىشـوند. بيشـتر كونسههـاى كيـاهى متعلـق بـهـ ايسن دو خـروه اكولوزيك، از جمله كونههاى علفى و تروفيتهايى بــا بـــر ريـز

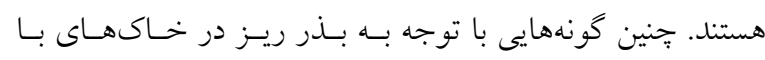
فشردكى كم و ماده آلى بالا در فصل بذرافشانى مىتوانند بهتر در خاك نفوذ كنند و در فصل رويش در رويشخاه استقرار بيدا كنند.

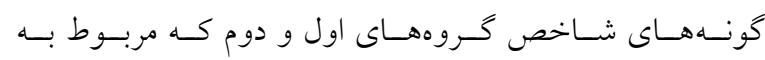

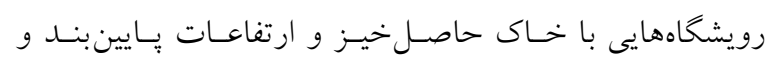
ميانبند هستند؛ حضور اين گونهها در مطالعات ديخر در ناحيـه

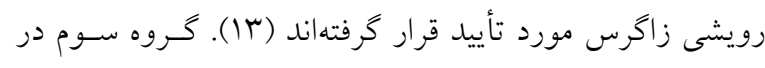
نقطه مقابل گروه اول و دوم قرار گرفته اسـت. ايسن خـروه كـه نـ

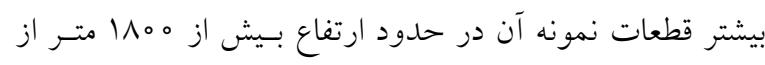
سطح دريا قرار كرفته با مشخصسههـاى ارتفـاع از سـطح دريـا، هـدايت الكتريكسى، وزن مخصــوص ظـاهرى و درصـــ شـنـ

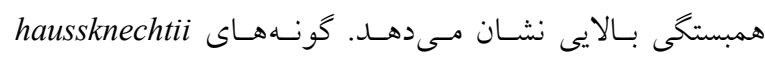
و Phlomis persica Astragalus gossypinus Artemisia Artemisia aucheri بيشتر گونههاى گروه سوم به خصوص گونههـاى شـاخص كـه

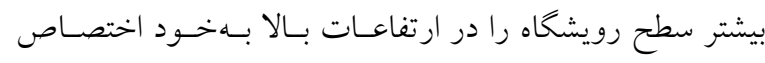
دادهاند جزء كونههاى مقاوم در برابر شرايط سخت رويشـاهى هستند. اين گونهها در مطالعات روى خــاكهـاى سـخخلاخى و شرايط سخت محيطى خـزارش شـدهانــ (ه). ريشـه نفـوذى و عميق از دلايل اصلى حضور اين گونههـا در شـرايط يـاد شــده 
شده كبيركوه زاكرس بيان كردند كه تنوع كونهاى بـا ارتفـاع از

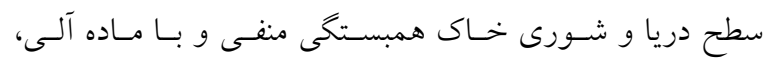
نيتروزن همبستخى مثبت دارد كه نتايج حاصل از اين مطالعه نيز مؤيد اين مطلب است (I (I).
تنوع و غنا مشخص شد كه كروه سـوم كـه در دامنسه ارتفــاعى

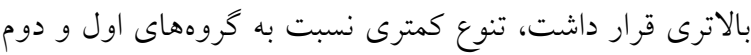
دارا بود. مطابق با نتايج تحقيق حاضر، مهدوى و همكاران (Ir)

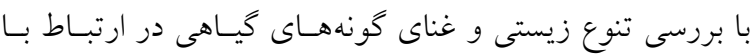

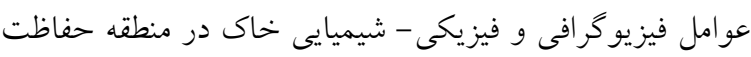

منابع مورد استفاده

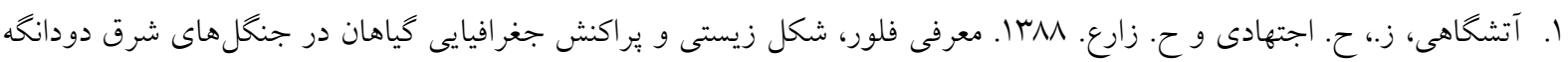

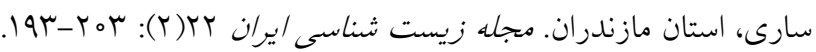

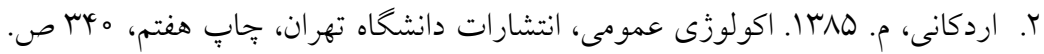

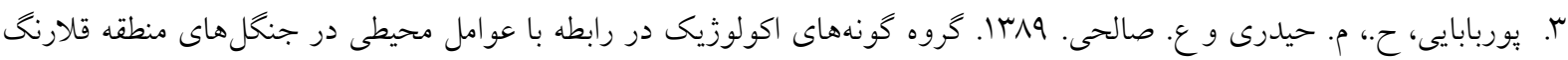

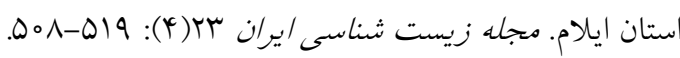

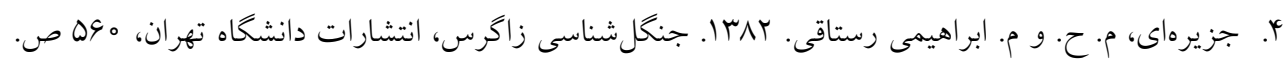

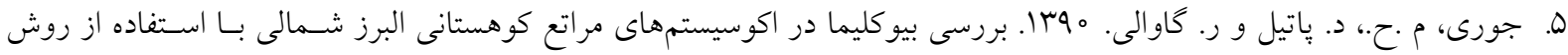

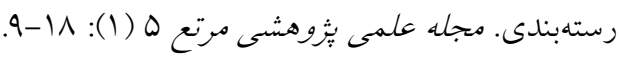

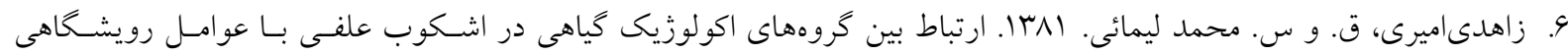

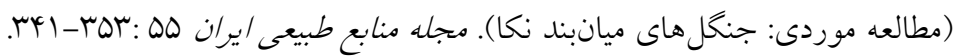

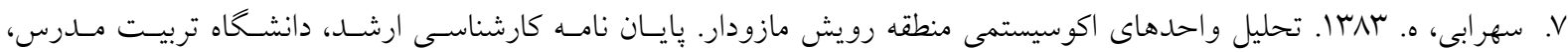

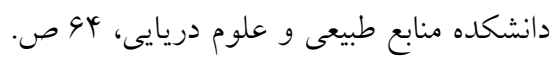

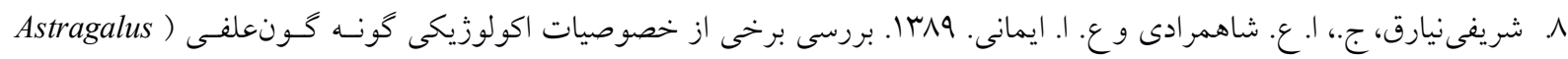
(brachyodontus

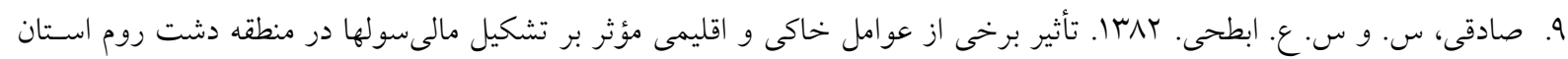

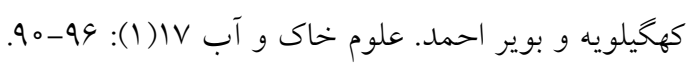

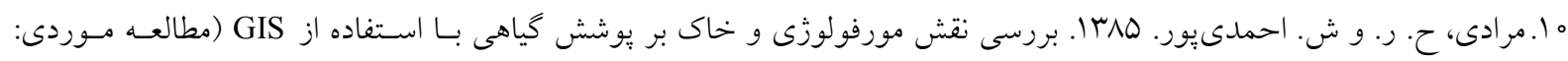

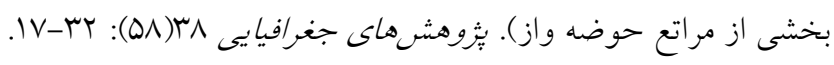

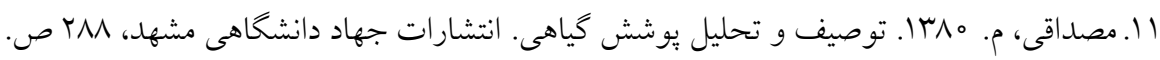

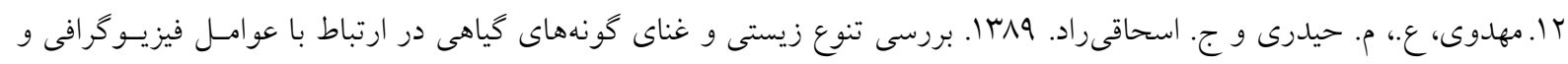

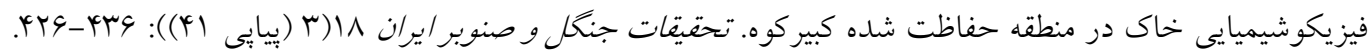

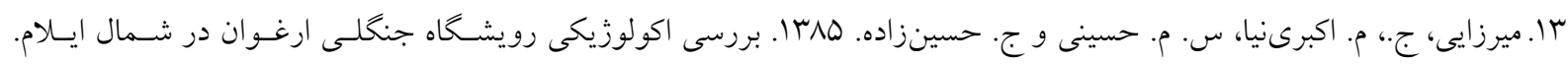

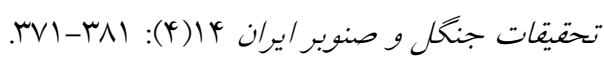

14. Adel, M. N., H. Pourbabaei and D. C. Dey. 2014. Ecological species group-environmental factors relationships in unharvested beech forests in the north of Iran. Ecological Engineering 69: 1-7.

15. Archambullt, L., B. V. Barnes and J. A. Witter. 1989. Ecological species groups of oak ecosystem of southeastern 
Michigan. Forest Science 35(4): 1058-1074.

16. Bajtala, M. J. 1999. Spatial patterns of duff consumption in Black spruce and Jack pine stands in the Boreal mixed wood forest. For the degree of Master of Science. National library of Canada.

17. Barnes, B. V., D. R. Zak and S. H. Spurr. 1998. Forest Ecology, John Wiley and Sons Inc, New York, 774 p.

18. Christine, J. S. and B. C. McCarthy. 2005. Relationship of understory diversity to soil nitrogen, topographic variation, and stand age in an eastern Oak forest, USA. Forest Ecology and Management 217(1): 230-243.

19. Dufrene, C. T. and C. T. Legender. 1997. The effect of logging and slash burning on soil structure. Advances in Soil Science 21(1): 444-447.

20. Heydari, M. and A. Mahdavi. 2009. The survey of plant species diversity and richness between ecological species groups (Zagros Ecosystem, Ilam). Journal of Applied Sciences 9(4): 745-751.

21. Jabeen, T. and S. S. Ahmad. 2009. Multivariate analysis of environmental and vegetation data of Ayub National Park Rawalpindi. Soil and Environment 28(2): 106-112.

22. Jangman, R. H. G., C. J. G. ter Break, and O. F. R. Van Tongeren. 1987. Data Analysis In. Community and Landscape Ecololgy, Pudoc, Wageningen, Jongman, pp. 91-212.

23. Kashina, D. M., B. V. Barnes and W. S. Walker. 2003. Ecological species groups of landform-level ecosystems dominated by Jack pine in northern lower Michigan, USA. Plant Ecology 166(1): 75-91.

24. Macune, B. and M. J. Mefford. 1999. PC-ORD for windows (software). Multivariate Analysis of Ecological Data, Version 3.1. MjM Software, Gleneden Beach, OR, USA.

25. Maranon, T., R. Ajbilou, F. Ojeda and J. Arroya. 1999. Biodiversity of woody species in oak woodland of southern Spain and northern Morocco. Forest Ecology and Management 115(1): 147-156.

26. Merzaei, J., M. Heydari, and P. Bernard, 2017. Effects of vegetation patterns and environmental factors on woody regeneration in semi-arid oak-dominated forests of western Iran. Journal of Arid Land 9(3): 368-378.

27. Pourbabaei, H. and T. Haghgooy, 2012. Plant species diversity in the ecological species groups in the Kandelat Forest Park, Guilan, north of Iran. Biodiversitas 13: 7-12.

28. Salifu, K. F., M. A. Nicidemus, D. F. Jacobs and A. S. Davis. 2006. Evaluating chemical indices of growing media for nursery production of Quercus rubur seedlings. Hort Science 41(1): 1342-1346.

29. Sebastia, M. T. 2004. Role of topography and soils in grassland structuring at the landscape and community scales. Basic and Applied Ecology 5(1): 331-346.

30. Smith, F. 1996. Biological diversity, Ecosystem stability and economic development. Ecological Economics 16(1): 191-203. 


\title{
Evaluation of Understory Plant Species Diversity in Relation to Some Environmental Factors in Imamzadeh Abdollah Baghmalek Forests
}

\author{
S. Attarroshan ${ }^{1 *}$ and M. Heydari ${ }^{2}$
}

(Received: March 29-2017; Accepted: Oct. 23-2018)

\begin{abstract}
This study aimed to investigate plant species diversity in the ecological species group in relation to the environmental factors. A study area of 216 ha in the southeast of Baghmalek on which seventy $20 \times 20 \mathrm{~m}$ plots were established according to the random-systematic method was selected. Soil properties and physiographic factors were recorded at each plot. Herbaceous species composition was recorded using four $1 \times 1 \mathrm{~m}$ subplots around the center of the main plot. A cluster analysis and a CCA analysis were undertaken and three ecological groups were identified. The results showed that $\mathrm{pH}$, Nitrogen, cation exchange capacity, organic carbon and clay percentage were the most important factors of the first group, and the indicator species were, Agropyrom trichophorum, Hordeum bulbosum, Aegilops triuncialis. The second group with Bromus tectorum, Salvia macrosiphon, Bromus danthonia as indicator species could be correlated with clay, organic carbon, Potassium, Phosphorous, Nitrogen, values. Lastly, the third group, characterized by Artemisia aucheri, Astragalus gossypinus, Phlomis persica, Artemisia haussknechtii as the indicator species, could be correlated with the elevation percentage of sand, Bulk Density and EC. We also found that species diversity varied significantly among the groups, and it was the highest in the first group and the lowest in the third group. The results could, therefore, contribute to better evaluation of species diversity and management of the biodiversity.
\end{abstract}

Keywords: plant species diversity, ordination, richness, Khuzestan.

1. Dept. of Environ., Ahvaz branch, Islamic Azad Univ., Ahvaz, Iran.

2. Dept. of forest sci., Faculty of Agric., Ilam Univ., Ilam Iran.

*: Corresponding Author, Email: Sina_2934@yahoo.com 